\title{
Lower Homerian (Silurian) Pristiograptus from the Zdanów section, Bardo Mountains (Sudetes, Poland) and their palaeobiogeographical implications
}

\author{
Sigitas Radzevičlus, Pawet Raczyński \& Misha Whittingham
}

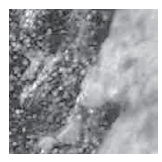

\begin{abstract}
Pristiograptus dubius pseudodubius and Pristiograptus lodenicensis were collected from outcrops of black pelagic shales of the Zdanów section of the Bardo Mountains (Sudetes, Poland). The species are easily distinguished from one another in that $P$. lodenicensis has distinct lobate processes on its thecae, whereas those of $P$. $d$. pseudodubius are comparatively unornamented. Our findings indicate that the age of the Lower Graptolitic Shales in the Zdanów is the middle part of the $C$. lundgreni graptolite Biozone (lower Homerian, upper Wenlock). The presence of $P$. $d$. pseudodubius at this site adds another locality to its global range, while the presence and abundance of $P$. lodenicensis further indicates the restriction of the latter species to the Rheic palaeo-ocean. - Key words: Homerian, Silurian, Bardo Mountains, Sudetes, Poland, Pristiograptus, Graptoloidea.
\end{abstract}

Radzevičius, S., Raczyński, P. \& Whittingham, M. 2020. Lower Homerian (Silurian) Pristiograptus from the Zdanów section, Bardo Mountains (Sudetes, Poland) and their palaeobiogeographical implications. Bulletin of Geosciences 95(2), 231-242 (5 figures). Czech Geological Survey, Prague. ISSN 1214-1119. Manuscript received November 5, 2019; accepted in revised form April 17, 2020; published online May 9, 2020; issued May 30, 2020.

Sigitas Radzevičius, Department of Geology and Mineralogy, Vilnius University, M. K. Čiurlionio 21/27, LT-03101, Vilnius, Lithuania; sigitas.radzevicius@gf.vu.lt • Pawet Raczyński Institute of Geological Sciences, University of Wroctaw, Pl. Maksa Borna 9, Wroctaw 50-205, Poland • Misha Whittingham, Department of Earth Sciences, Carleton University, 1125 Colonel By Drive, Ottawa, Ontario, Canada K1S 5B6

The genus Pristiograptus (Graptoloidea) has been recorded from the Llandovery to the upper Přídolí, but is most common in the Wenlock-Ludlow interval and is one of the longest ranging monograptid genera. The genus is characterized by cylindrical thecae without distinct apertural processes and a slightly curved or straight, simple rhabdosome (after Urbanek 1958). This conservative monograptid group survived all of the Wenlock-Ludlow biotic crises and radiated and prospered while populations of other monograptids decreased. After those biotic crises new genera of monograptids developed from Pristiograptus via speciation and adaptive radiation. The extinction of the Pristiograptus lineage was the penultimate "nail in the coffin" of monograptid evolution.

Jaekel (1889) erected the genus Pristiograptus. According to him, the rhabdosome of Pristiograptus is unbranched, is straight or a little curved, the thecae are cylindrical, inclined to rhabdosome axis, the thecal mouth opening free (the mouths of the thecae are not covered by any lid or hood) and, if present, apertural processes stand as spines at the lower edge of the mouth. Today, some of Jaekel's Pristiograptus taxa are assigned to other genera [e.g. Testograptus testis (Barrande)]. Přibyl (1943) revised Pristiograptus based on material from Czechia and lit- erature data, producing the first catalogue of the genus. Münch (1952) assembled his own summary of known graptolites, including Pristiograptus, and presented short descriptions and illustrations of all known taxa. This was later followed up by phylogenetic studies of Pristiograptus and related genera presented by Rickards \& Wright (2003), Radzevičius (2003), Radzevičius et al. (2008), Urbanek et al. (2012) and Whittingham et al. (2020). In short, the taxa of Pristiograptus genera are well known and very important for graptolite evolution and palaeogeography.

Only one problematical species, Pristiograptus frequens Jaekel (described as having thecae of colonus type, as opposed to the unornamented thecae typical of P. frequens), has been recorded from the Zdanów outcrop (Malinowska 1955), although graptolites are common there. Surprisingly, there have been very few graptolite studies based on material from the Zdanów outcrop, despite graptolites from the lower Silurian to the lower Devonian in this section being very common in this section. The Zdanów outcrop is thus very important in the Sudetes region because of its considerable stratigraphical extent.

In this work two species of Pristiograptus are documented for the first time from the Sudetes Mountains. We 


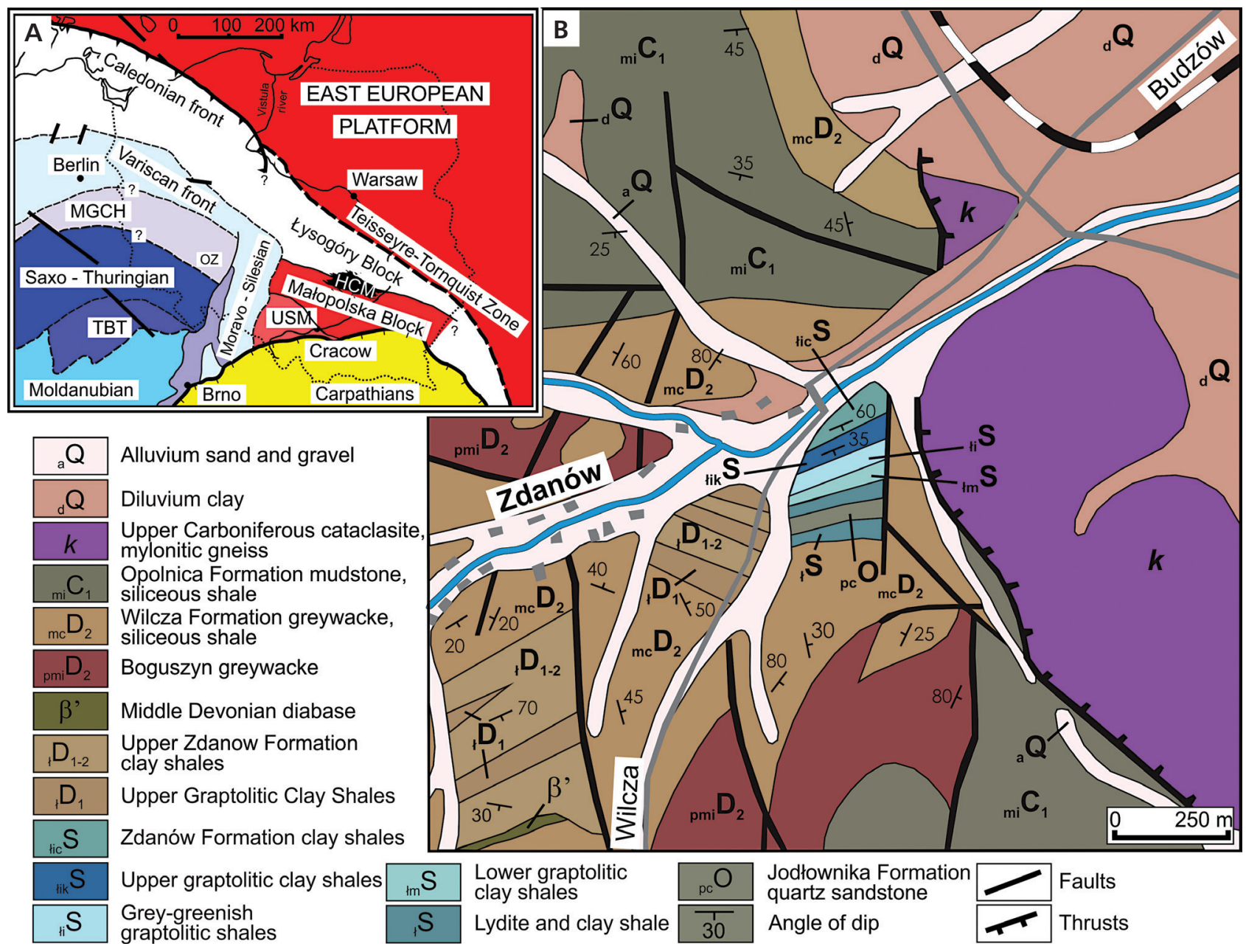

Figure 1. A - simplified structural map of central Europe (Bełka et al. 2002). Abbreviations: HCM - The Holy Cross Mountains; MGCH - Mid German Crystalline High; OZ - Odra Zone; TBT - Tepla-Barrandian Terrane; USM - Upper Silesian Massif. • B - geological map of the Bardo Mountains with the Zdanów outcrop location (Oberc et al. 1994).

present detailed descriptions of flattened pristiograptids that enable a better understanding of the morphology of the taxa and expand our knowledge of the palaeogeographical range of these species of Pristiograptus.

\section{Geological setting and material}

The Bardo Mountains (Góry Bardzkie) are located in the Central Sudetes (Żelaźniewicz \& Aleksandrowski 2008) and assigned to the European Variscides Belt, which runs from Central Poland in the East to southern Portugal in the West (Mazur et al. 2006). The Central European Variscides Belt is subdivided into several zones (Fig. 1A). The Silurian sections of the Bardo Mountains are assigned to the Saxothuringian zone (Porębska \& Sawłowicz 1997), part of the Armorican Terrane Assemblage (Franke 2000). The Armorican Terrane Assemblage is considered to have been located in the southern part of the Rheic Ocean during the Silurian (Winchester et al. 2002).

There are several small Silurian outcrops in the Bardo Mountains. The most complete Silurian geological section is the Zdanów outcrop which is located on the road from Budzów to Wilcza (Fig. 1B) near Zdanów village (N 50 $33^{\prime} 43.2^{\prime \prime}$, E $\left.16^{\circ} 39^{\prime} 55.0^{\prime \prime}\right)$.

Graptolites from the Zdanów outcrop have been known since the $19^{\text {th }}$ century. Looking for resources of coal, Krug von Nidda (1853) described black shales with graptolites in the Zdanów area and documented Graptolithus priodon [= Monograptus priodon (Bronn)]. Frech (1897) described the new genus Monoclimacis and several other graptolites from Zdanów (in German Herzogswalde). Through graptolite biostratigraphy, Frech (1897) determined that the rocks of the Zdanów outcrop belonged to the Wenlock and Ludlow series. Dathe (1904) supposed that part of the Zdanów (the Zdanów 
beds) outcrop was early Devonian in age. The first Silurian graptolite zonal scale for the Bardo Mountains was given by Dahlgrün \& Finckh (1924). Hundt (1924) also confirmed that Ludlow age rocks crop out in Zdanów. Malinowska (1955) later investigated graptolites from the Llandovery-Ludlow interval in the Zdanów outcrop. She described more than 50 graptolite species and provided a detailed graptolite biozonation. Jaeger (1959) described the new graptolite species Monograptus silesicus and Monograptus praehercynicus based on material from Zdanów. Teller $(1959,1960)$ investigated graptolites from the Silurian-Devonian boundary interval. The graptolite stratigraphy, especially that of the uppermost Silurian and lowermost Devonian, was investigated by Porębska (1980a, 1982; Porębska \& Sawłowicz 1997), and a short report on the local graptolites was given by Kurałowicz (1976).

The thickness of Silurian strata is about $50 \mathrm{~m}$ in Zdanów (Porębska 1980b, Wyżga 1987) and represents pelagic sediments. These are distinguished as the Lower Graptolitic Shales, the Green Shales and the Upper Graptolitic Shales (Wyżga 1987). The Silurian shales overlie the light-coloured sandstone and clay shales of the Upper Ordovician Jadłownik Beds (Chorowska \& Oberc 1980). The lithology of all units is represented by lydites (radiolarian cherts), clay shales with tephra interbeds, and phosphatic nodules (Porębska \& Koszowska 2001). The Lower Graptolitic Shales span the Parakidograptus acuminatus-Lobograptus scanicus biozones, the Green Shales the Saetograptus leintwardinensis-Neocolonograptus ultimus biozones, and the Upper Graptolitic Shales the Monograptus transgrediens-Monograptus craigensis biozones (Porębska \& Sawłowicz 1997).

Our new material comes from the Lower Graptolitic Shales (Fig. 2). The graptolite finds from the lundgreni Biozone are solely in our collection due to limited collecting. Monograptus flemingii (Salter) (Fig. 3A) and Testograptus testis (Barrande) (Fig. 3B) have been identified together with Pristiograptus dubius pseudodubius (Bouček) and Pristiograptus lodenicensis Přibyl. Testograptus testis indicates the mid-upper lundgreni Biozone of the lower Homerian. Monograptus flemingii ranges from the riccartonensis Biozone to the topmost lundgreni Biozone and is a typical Wenlock monograptid.

\section{Systematic palaeontology}

The classification and morphological terminology of pristiograptids is after Urbanek et al. (2012) and two

Figure 2. Silurian cross section of the Zdanów outcrop (Porębska \& Koszowska 2001). The star marks the approximate sampling position.
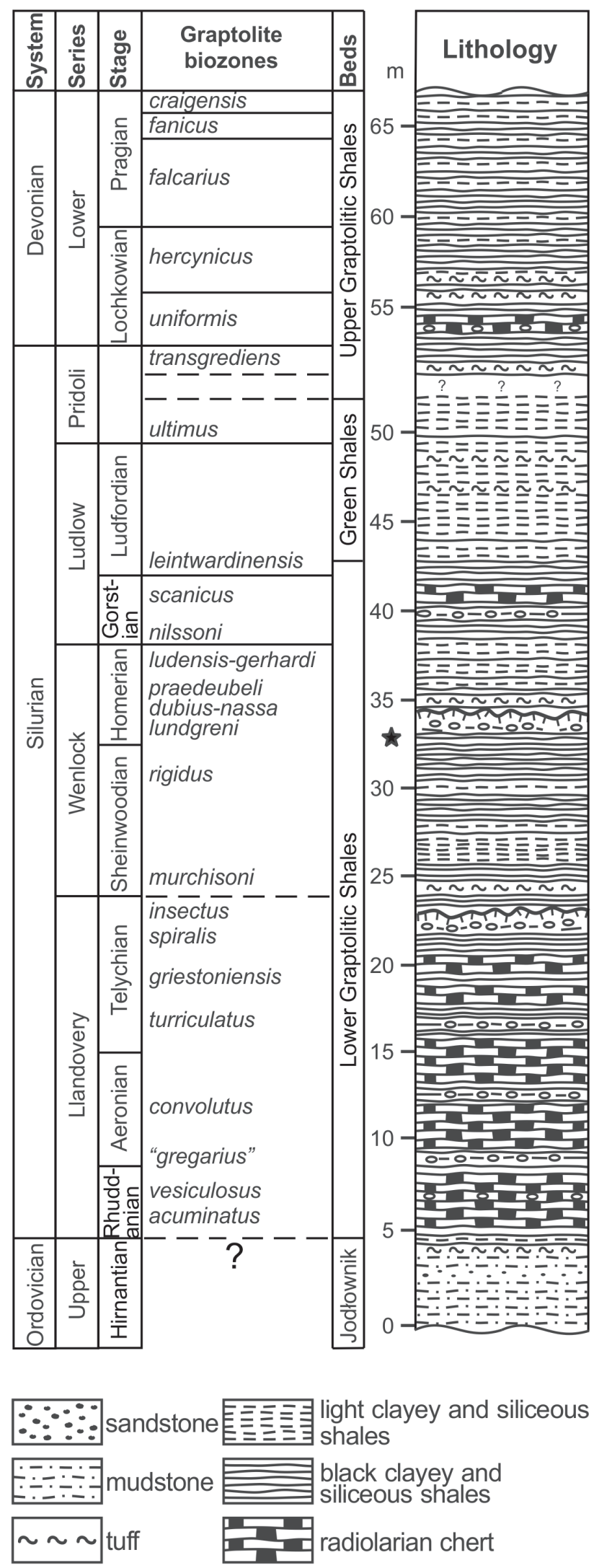

궁중여 phosphatic concretions and encrustations 
thecae repeat distance (2TRD after Howe 1983). Material is stored at the Department of Geology and Mineralogy of Vilnius University.

Order Graptoloidea Lapworth, 1873

Family Monograptidae Lapworth, 1873

Subfamily Pristiograptinae Gürich, 1908

\section{Genus Pristiograptus Jaekel, 1889}

Type species. - Pristiograptus frequens Jaekel, 1889, from erratic boulders from Świebodzice (Freiburg Schlesien) and Nowa Sol (Neusalz on Oder) Lower Silesia (Poland), Lobograptus scanicus Biozone, lower Ludlow.

Diagnosis. - Rhabdosome variable in length, straight or gently curved. Thecae are straight, simple cylindrical, generally uniform throughout the rhabdosome, varying in degrees of inclination to the rhabdosome axis and amount of overlap. Aperture is without any distinct structures. Ventral wall quite straight with a clear thecal apertural lip.

Remarks. - Widely used diagnosis of Pristiograptus genus is incomplete and mostly corresponding to Pristiograptus of Wenlock-Přídolí interval. There are some strongly dorsal or ventral curved Pristiograptus species in the upper Aeronian and lower Telychian (Llandovery). The dorsally curved rhabdosome have $P$. xiushanensis NIGP (Loydell et al. 2015), P. renaudi (Philippot) (Štorch \& Massa 2006). Loydell \& Walasek (2020) describe Pristiograptus paradoxus with ventrally curved rhabdosome. Pristiograptus from Llandovery needed revision and perhaps will be placed in a separate genus in the future or the diagnosis of Pristiograptus will need to be revised. However, that problem will not be discussed herein.

\section{Pristiograptus dubius pseudodubius (Bouček, 1932)} Figure $3 \mathrm{C}-\mathrm{E}$

1932 Monograptus pseudodubius; Bouček, pp. 1, 2, fig. 2e, f, pl. 8, fig. 3 .

1943 Pristiograptus pseudodubius (Bouček). - Přibyl, pp. 8, 9, pl. 1, figs 1,3 .

1952 Pristiograptus pseudodubius (Bouček). - Münch, p. 86, pl. 18 , fig. 7.

1965 Pristiograptus pseudodubius (Bouček). - Jaworowski, pl. 1, fig. 12, text-fig. 9 .

1965 Pristiograptus pseudodubius (Bouček). - Obut et al., p. 72, pl. 13, fig. 2.

1965 Pristiograptus pseudodubius (Bouček). - Rickards, p. 260 , pl. 29 , fig. 10 , text-fig. 2 i.

1967 Pristiograptus pseudodubius (Bouček). - Gailite et al., pp. 243, 244, pl. 18, figs 8, 9, text-fig. 57.
1974 Pristiograptus pseudodubius (Bouček). - Ulst, pp. 108, 109, pl. 11, fig. 1, pl. 12, figs 1, 2.

1999 Pristiograptus dubius cf. pseudodubius (Bouček). Zalasiewicz \& Williams, fig. $9 \mathrm{~m}$.

2000 Pristiograptus pseudodubius (Bouček). - Radzevičius \& Paškevičius, pp. 92-94, pl. 2, fig. 1.

2008 Pristiograptus pseudodubius (Bouček). - Sachanski et al., p. 389, fig. 4.7.

2012 Pristiograptus dubius pseudodubius (Bouček). Sachanski et al., p. 872, pl. 2, fig. e.

2012 Pristiograptus dubius pseudodubius (Bouček). Urbanek et al., p. 600, figs 5b, 6a, 7c, d.

Material. - Four asymmetrical flattened rhabdosomes from the Zdanów outcrop, Bardo Mountains, Lower Silesia, Poland, the lundgreni Biozone, the Lower Graptolitic Shales, Homerian.

Description. - Rhabdosome is narrow and either straight or slightly ventrally curved. The width (W) of the rhabdosome gradually increases from $0.7 \mathrm{~mm}$ at th1, $0.75 \mathrm{~mm}$ at th $2,0.8 \mathrm{~mm}$ at th $3,1 \mathrm{~mm}$ at th $4,1.1 \mathrm{~mm}$ at th5. Value of $\mathrm{W}_{\max }$ is $1.5 \mathrm{~mm}$. The interapertural width is $0.55 \mathrm{~mm}$ at th $1,0.65 \mathrm{~mm}$ at th $2,0.75 \mathrm{~mm}$ at th $3,0.85 \mathrm{~mm}$ at th $4,0.9 \mathrm{~mm}$ at th5. The 2TRD measurements are 1.6$1.9 \mathrm{~mm}$ (th2), $1.7-2 \mathrm{~mm}$ (th3), $1.6-2 \mathrm{~mm}$ (th4), $1.9-2 \mathrm{~mm}$ (th5) and $2-2.5 \mathrm{~mm}$ in medially and distally. Thecae are cylindrical; apertures possess a pronounced lip which extends half way up the outer wall of the succeeding theca. The angle ( $\beta$ angle) between the thecal apertural lip and the succeeding metathecal wall is obtuse (Fig. $3 \mathrm{D}_{2}$ ). No sicula are adequately preserved for measurement in any of the specimens.

Remarks. - Pristiograptus $d$. pseudodubius can be easily mistaken for other subspecies of $P$. dubius. Width of $P . d$. dubius (Suess) is $0.8 \mathrm{~mm}$ at th $1,1.0 \mathrm{~mm}$ at th $2,1.1 \mathrm{~mm}$ at th3, $1.25 \mathrm{~mm}$ at th4 and it is slightly greater than in $P . d$. pseudodubius. Pristiograptus $d$. parvus is smaller than $P$. d. pseudodubius. The rhabdosome of $P$. $d$. parvus widens from $0.6 \mathrm{~mm}$ at th $1,0.7 \mathrm{~mm}$ at th $2,0.8 \mathrm{~mm}$ at th $3,0.85 \mathrm{~mm}$ at th4. The rhabdosome of $P$. $d$. parvus is reduced in size as a result of so-called Lilliput effect (Urbanek et al. 2012).

The significant differences of $P$. dubius stem lineage subspecies are in the extension of the thecal apertural lip. The species sits directly above $P$. d. dubius stratigraphically, differing in morphology by the extension of the thecal apertural lip midway up the succeeding theca (Fig. 3C-E). Pristiograptus d. dubius has a thecal apertural lip ending at the beginning of the succeeding metathecal wall, and has a broader rhabdosome. The stratigraphically succeeding $P$. $d$. parvus Ulst bears even closer similarity to $P$. d. pseudodubius, also having a slender rhabdosome, 

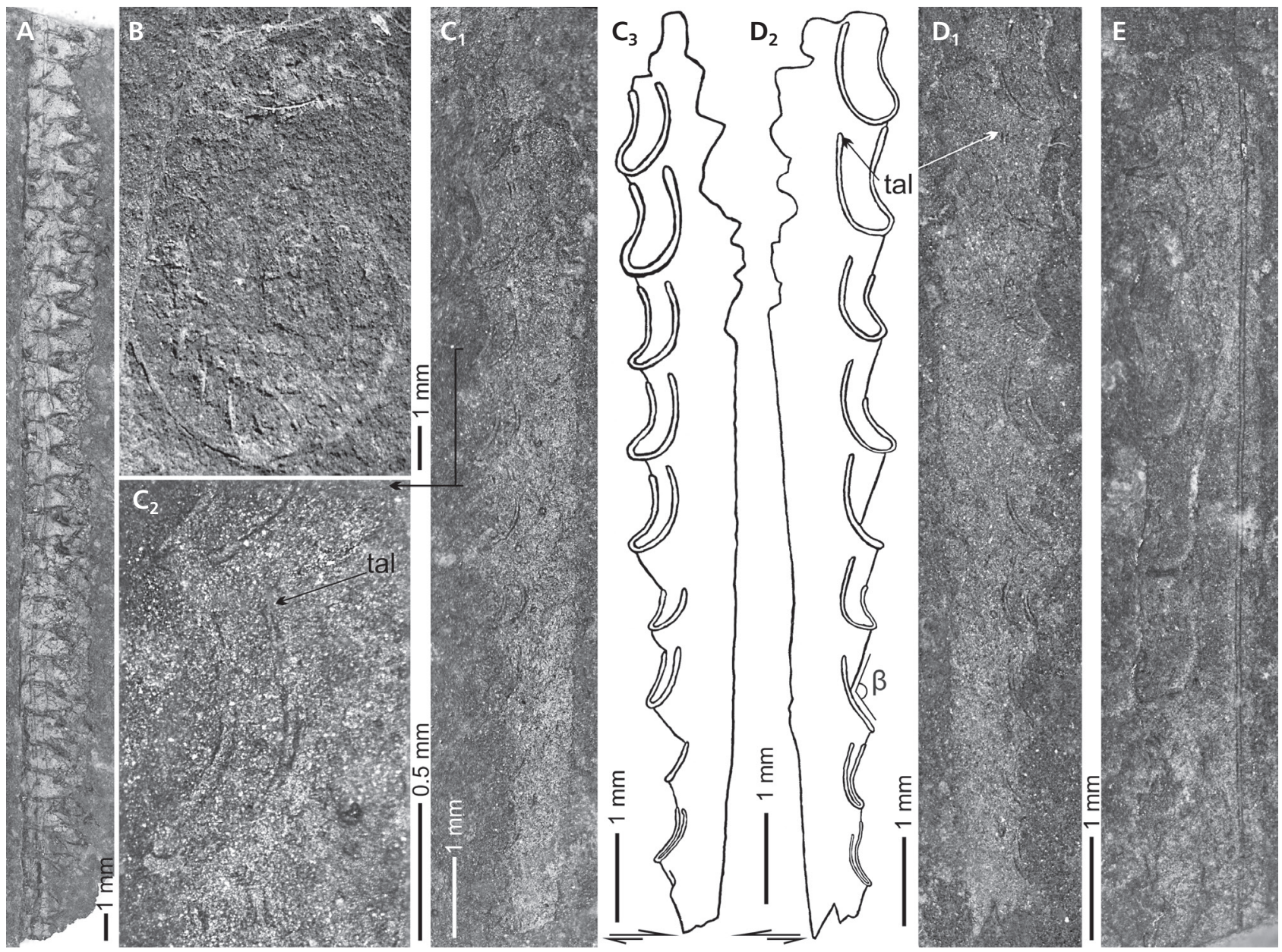

Figure 3. Graptolites from the Zdanów outcrop, the Bardo Mountains, Sudetes, South West Poland, Lower Graptolitic Shales, lundgreni Biozone, Homerian. • A - Monograptus flemingii (Salter), no. ZDW-A3-0055. • B - Testograptus testis (Barrande), no. ZDW-A3-0029. $・$ C-E - Pristiograptus dubius pseudodubius (Bouček); C - no. ZDW-A3-07; $\mathrm{C}_{1}$ - general view of rhabdosome; $\mathrm{C}_{2}-$ thecae apertural lip (tal); $\mathrm{C}_{3}-$ interpretive drawing of specimen; D - no. ZDW-A3-0020; $\mathrm{D}_{1}$ - general view of rhabdosome; $\mathrm{D}_{2}$ - interpretive drawing of specimen; $\mathrm{E}$ - medial part of rhabdosome. Abbreviation: tal - thecal apertural lip.

though generally even more so than $P$. d. pseudodubius. $P$. d. parvus lacks thecal lips extending onto the wall of the succeeding theca, further distinguishing the species. Despite these differences, the two have been treated as synonymous in the past (e.g. Rickards \& Wright 2003).

The close morphological and stratigraphical relationship between the three above-mentioned taxa has resulted in the inference of their inclusion in the central P. dubius stem lineage (Urbanek et al. 2012, Whittingham et al. 2020). The inclusion of $P$. $d$. dubius, $P . d$. pseudodubius and $P . d$. parvus with that anagenic stem lineage supports their status as subspecies of Pristiograptus dubius under a lineage species concept (sensu de Quieroz 1998, 2007), as outlined and recommended by Whittingham et al. (2020).

Occurrence. - Monograptus belophorus-Cyrtograptus lundgreni biozones of the Wenlock. Range of geographical distribution is broad, spanning Arctic Canada (Lenz \& Kozłowska-Dawidziuk 2001, Lenz et al. 2012), Australia (Rickards \& Sandford 1998), Czech Republic (Bouček 1932, Přibyl 1943), England (Rickards 1965), Ireland (Rickards et al. 1973, Doran 1974), Latvia (Ulst 1974), Libya (Štorch \& Massa 2003), Lithuania (Radzevičius \& Paškevičius 2000), Poland (Jaworowski 1965, Urbanek et al. 2012), Romania (Iordan 1992, Colţoi et al. 2016), Sardinia (Italy) (Štorch \& Piras 2009) Serbia (Krstić et al. 2005), South China (Xu 1984), Turkey (Sachanski et al. 2008, 2012), Vietnam (Thanh et al. 2013) and Wales (Warren et al. 1984).

\section{Pristiograptus lodenicensis Přibyl, 1943}

Figure 4

1943 Pristiograptus lodenicensis; Přibyl, pp. 23, 24, pl. 3, figs $8-11$, text-figs c, d, j, k. 
1952 Pristiograptus lodenicensis Přibyl. - Münch, p. 91, pl. 20, fig. 7.

1965 Pristiograptus lodenicensis Přibyl. - Jaworowski, pp. 522, 523, pl. 1, fig. 10, text-fig. 13.

1967 Pristiograptus lodenicensis Přibyl. - Gailite et al. p. 244, pl. 29, figs 4, 5, text-fig. 58.

1974 Pristiograptus lodenicensis Přribyl. - Ulst, p. 115, pl. 11, fig. 7, pl. 13, figs 1, 2.

2000 Pristiograptus lodenicensis Přibyl. - Radzevičius \& Paškevičius, pp. 97, 98, pl. 4, fig. 1, 2, pl. 6d.

2003 Pristiograptus lodenicensis Přibyl. - Radzevičius, pp. 10, 11, figs 11a-h, 12a-f.

2005 Pristiograptus lodenicensis Přibyl. - Radzevičius \& Paškevičius, p. 165, pl. 2, fig. f.

2006 Pristiograptus lodenicensis Přibyl. - Radzevičius, p. 337 , fig. $4 \mathrm{c}-\mathrm{f}$.

2012 Pristiograptus lodenicensis Přibyl. - Urbanek et al. p. 606, figs 4b, 5h, 6g, 10.

Material. - More than ten flattened rhabdosomes, of proximal and medial parts, from the Zdanów outcrop, Bardo Mountains, Lower Silesia, Poland, the lundgreni Biozone, the Lower Graptolitic Shales, Homerian.

Description. - Rhabdosome is straight and broad. The width of the rhabdosome gradually increases from $0.75 \mathrm{~mm}$ at th1, $0.8 \mathrm{~mm}$ at th2, $0.95 \mathrm{~mm}$ at th $3,1.1 \mathrm{~mm}$ th $4,1.25 \mathrm{~mm}$ at th5. Value of $\mathrm{W}_{\max }$ is $1.8 \mathrm{~mm}$. The interapertural width is $0.5 \mathrm{~mm}$ at th $1,0.6 \mathrm{~mm}$ at th2, $0.7 \mathrm{~mm}$ at th3, $0.8 \mathrm{~mm}$ at th $4,0.85 \mathrm{~mm}$ at th5, with $\mathrm{W}_{\max }$ being $1.5 \mathrm{~mm}$. The 2TRD measurements are $1.0-1.3 \mathrm{~mm}$ (th2), 1.1-1.4 mm (th3), 1.4-1.5 mm (th4), 1.4-1.5 mm (th5) and $1.7-2.0 \mathrm{~mm}$ in medially and distally. The $\beta$ angle between the thecal apertural lips is right or acute (Fig. 4). The thecal apertural lip is narrow with symmetrical lateral elevations (e.g. Fig. $4 \mathrm{C}_{1}, \mathrm{~F}$ ) or "manta ray wings" of cortical tissue and ventral incision (e.g. Fig. 4F). The development of the lateral elevations increases with astogeny. The sicula is ventrally curved, and bears a short virgella. The length of the sicula is $1.3 \mathrm{~mm}$. The sicula apex reaches the aperture of the second theca.

Remarks. - These traits make P. lodenicensis easily identifiable, particularly in the lundgreni Biozone, and allowed us to place the previously unassigned Pristiograptus sp. 1 of Holland et al. (1969) in P. lodenicensis as the morphological characters, particularly those of thecal width, $\beta$ angle, and apertural shape, all fit comfortably into the range of morphology seen in $P$. lodenicensis elsewhere (e.g. Urbanek et al. 2012).

The lateral elevations on the thecae of $P$. lodenicensis make this species easily distinguishable from other monograptids that occur in the C. lundgreni Biozone. Within this biozone $P$. praelodenicensis Urbanek et al. from Poland bears closest resemblance to $P$. lodenicensis. It also possesses a right or acute $\beta$ angle. However, $P$. praelodenicensis lacks thecal lateral elevations and has a narrower rhabdosome. Width of $P$. praelodenicensis is $0.7 \mathrm{~mm}$ at th1, $0.85 \mathrm{~mm}$ at th2, $1.0 \mathrm{~mm}$ at th $3,1.2 \mathrm{~mm}$ at th4. The similarity between P. lodenicensis and P. praelodenicensis caused Urbanek et al. (2012) to treat the latter as an ancestor taxon to the former, with $P$. lodenicensis speciating shortly after the origin of P. praelodenicensis.

The bilateral processes are more commonly found on the thecae of later Silurian monograptids, appearing with varying exaggeration in Colonograptus, Saetograptus and Pristiograptus labiatus Urbanek. In particular, the similarity between $P$. lodenicensis and P. labiatus has been used as an example of Rickards \& Wright's (2003) iterative speciation in the Pristiograptus dubius stem lineage (Urbanek et al. 2012). The possible origination of each of these lobate taxa from a central stem appears to challenge the notion of morphospace "progress" in graptolites put forth by Pearson (1998), at least in the case of the $P$. dubius stem lineage.

Also of interest in the morphology of $P$. lodenicensis is the shift seen in thecal morphology with progressing astogeny. This is a pattern not seen in other species of Pristiograptus, instead being more diagnostic of the thecae of Colonograptus colonus (Barrande) and Saetograptus chimaera (Barrande). The patterns seen herein are exemplary of the morphogenic gradients outlined in Urbanek \& Uchmanski (1990) and Urbanek (2003). This would indicate that the same process may be at work in $P$. lodenicensis, with a diluting morphogen resulting in two separate astogenetic phases in the species.

Occurrence. - Cyrtograptus lundgreni Biozone of the lower Homerian, upper Wenlock. Ulst (1988) proposed distinguishing a $P$. lodenicensis Subzone in the middle part of T. testis Biozone (= middle part of C. lundgreni Biozone). Pristiograptus lodenicensis is known from Latvia (Gailite et al. 1967, Ulst 1974), Lithuania (Paškevičius 1983, Radzevičius \& Paškevičius 2005), the Polish part of the East Europe platform (Jaworowski 1965, Urbanek et al. 2012), the Polish part of the Sudetes Mountains (this paper), Thuringia (Jaeger 1959, 1991), Czech Republic (Přibyl 1943) and England (Holland et al. 1969) and Wales (Warren et al. 1984).

\section{Palaeobiogeography}

The long-ranging $P$. d. pseudodubius had a particularly widespread distribution during the middle Wenlock (Fig. 5). It occurs in Latvia (Ulst 1974), Lithuania (Radzevičius \& Paškevičius 2000) and northeastern Poland 

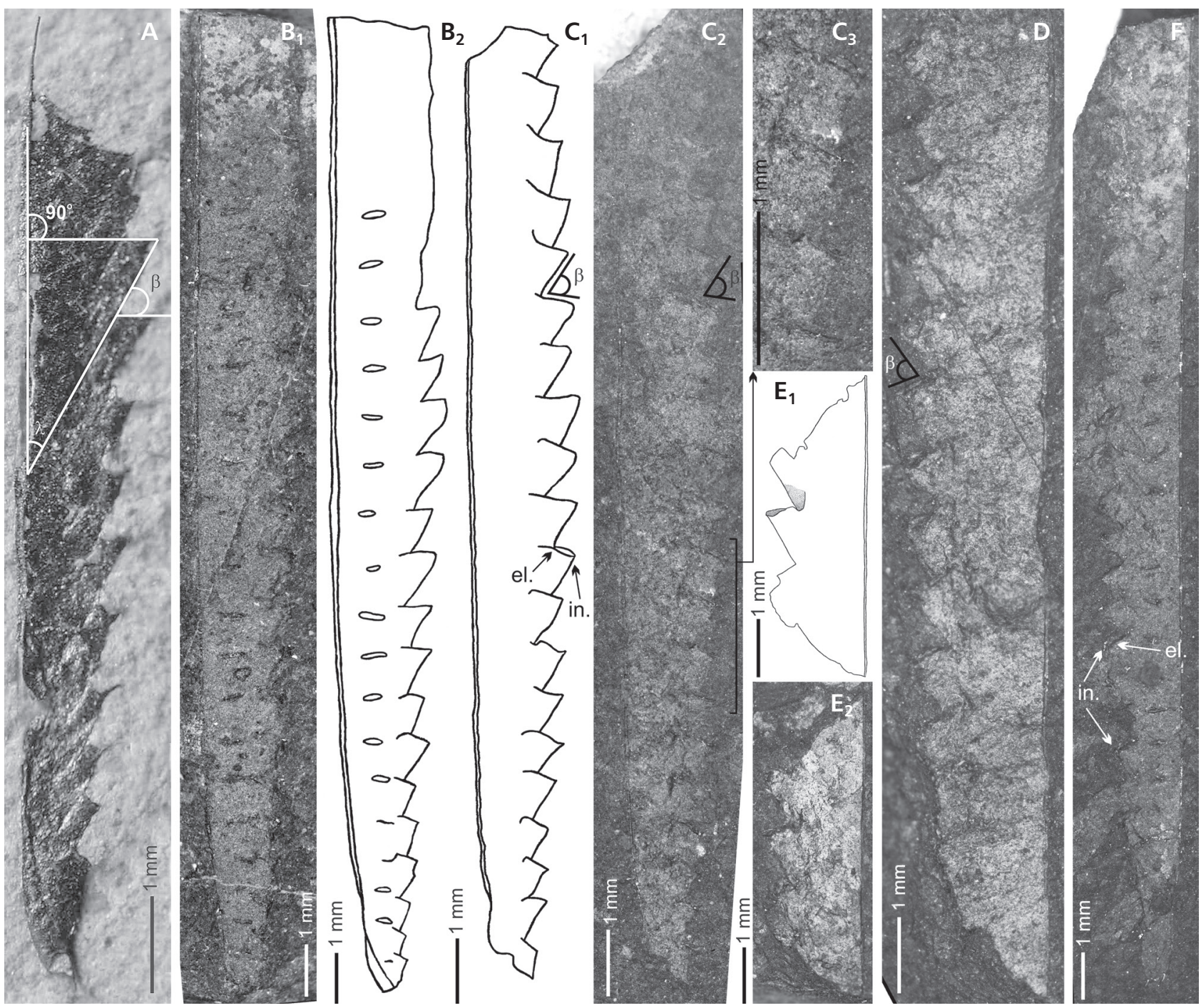

Figure 4. Pristiograptus lodenicensis Přibyl; A - no. VU-813 with the main morphological elements, Likenai-396 borehole, Lithuania, depth $589.5 \mathrm{~m}$, lundgreni Biozone, Riga Formation, Homerian; B - no. ZDW-A3-0030c, $\mathrm{B}_{1}$ - general view of rhabdosome, $\mathrm{B}_{2}-$ interpretive drawing of specimen; $\mathrm{C}$ - no. ZDW-A3-0053d, $\mathrm{C}_{1}$ - interpretive drawing of specimen, $\mathrm{C}_{2}$ - general view of rhabdosome, $\mathrm{C}_{3}-$ the form of thecal apertural lips; D - no. ZDW-A3-0048, medial part of rhabdosome; E - no. ZDW-A3-0022b, $\mathrm{E}_{1}$ - interpretive drawing of specimen, $\mathrm{E}_{2}$ - general view of rhabdosome; F - no. ZDW-A3-0043. Abbreviations: el. - lateral elevations; in. - incision.

(Jaworowski 1965, Urbanek et al. 2012) on the east part of the palaeocontinent Baltica and is also known from Bornholm (Bjerreskov \& Jørgensen 1983), another locality linked to Baltica. The species is documented from Northern England (Rickards 1965) and Denbighshire north-east Wales (Warren et al. 1984) part of the palaeocontinent Avalonia. There are also findings of $P$. d. pseudodubius near Balbriggan (Rickards et al. 1973) and Hollyford Slieve Phelim (Doran 1974) in Ireland. Both localities are a part of the Leinster Terrane (Chew \& Stillman 2009) and linked to the Avalonian side of the Iapetus Ocean (Cocks et al. 2003).

Pristiograptus d. pseudodubius is known from Czechia, often referred to the Perunica Terrane (Bouček 1932, Přibyl
1943), the Bardo Mountains part of the Saxo-Thuringia Terrane (this paper) and from Sardinia (Štorch \& Piras 2009), which was a part of the Iberia massif during the Silurian (Torsvik \& Cocks 2016). However, the Perunica and Saxo-Thuringia terranes, as well as Sardinia, are the part of Armorican terrane assemblage (Servais \& Sintubin 2009) which was located near Central Gondwana (Torsvik \& Cocks 2011) on the opposite side of the Rheic Palaeoocean with respect to Baltica during the Wenlock (Fig. 5). Pristiograptus d. pseudodubius is found in Romania (Iordan 1992, Colțoi et al. 2016) and Serbia (Krstić et al. 2005), localities in the Moesia Terrane (Torsvik \& Cocks 2004). The Moesia Terrane is located between the SaxoThuringian Terrane and Moesia, Istanbul, Pontides (Ruban 


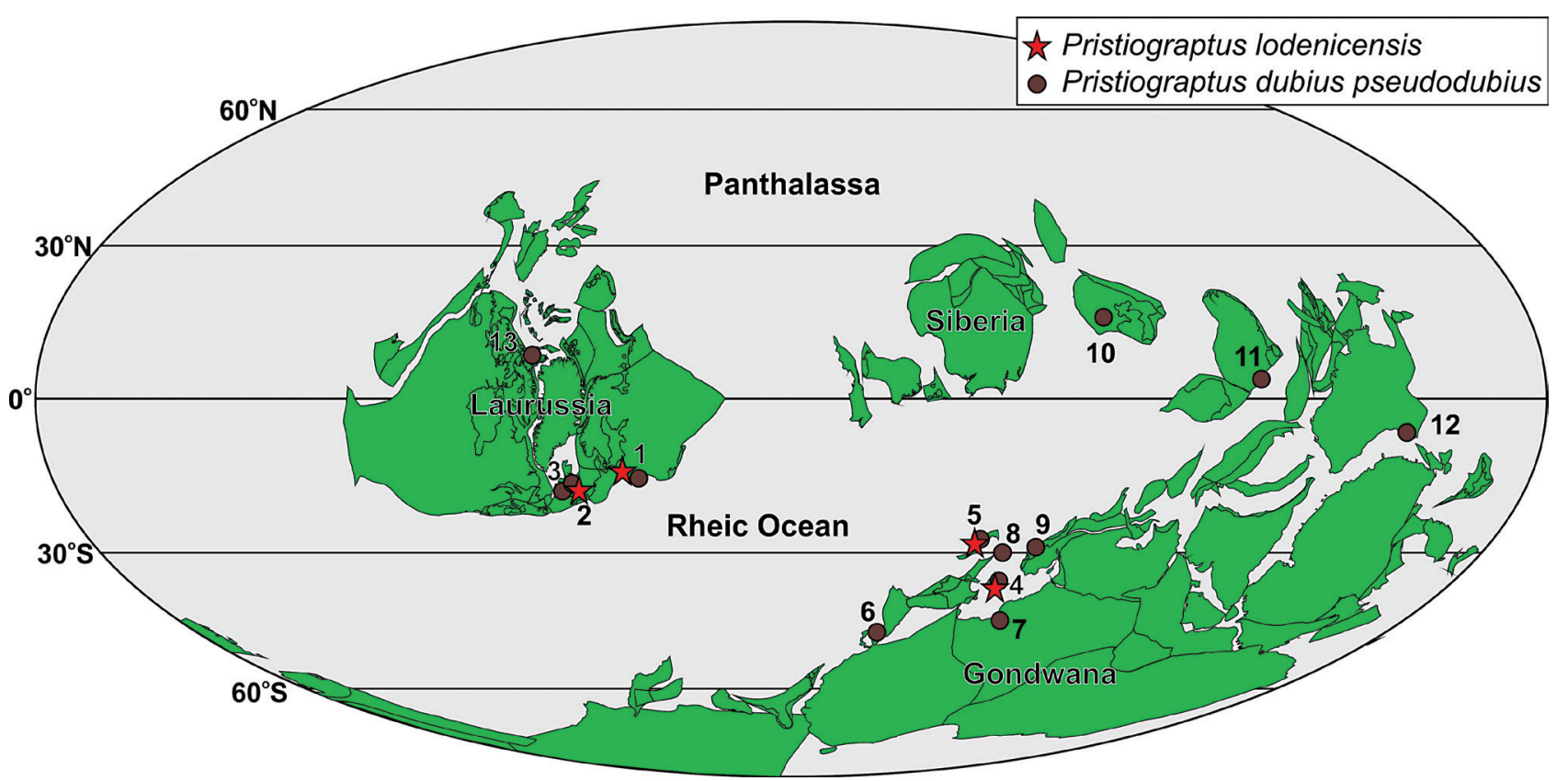

Figure 5. Late Wenlock palaeogeographical reconstruction (after Torsvik \& Cocks 2013) and palaeobiogeographical distribution of $P$. $d$. pseudodubius and P. lodenicensis. Abbreviations: 1 - Baltica [Bornholm (Bjerreskov \& Jørgensen 1983), Latvia (Ulst 1974), Lithuania (Radzevičius \& Paškevičius 2000), Poland (Jaworowski 1965, Urbanek et al. 2012) part of the East Europe platform]; 2 - Avalonia [Northern England (Rickards 1965)]; 3 - the Avalonia side of the Iapetus Ocean [Ireland (Rickards et al. 1973, Doran 1974, Chew \& Stillman 2009)]; 4 - the Perunica Terrane [Czech Republic (Bouček 1932, Přibyl 1943)]; 5 - the Saxo-Thuringia Terrane [Bardo Mountains Sudetes (this paper), Thuringia (Jaeger 1959, 1991)]; 6 - the Iberia massif [Sardinia (Štorch \& Piras 2009)]; 7 - central Gondwana [Libya (Štorch \& Massa 2003)]; 8 - the Moesia Terrane [Romania (Iordan, 1992, Colţoi et al. 2016) and Serbia (Krstić et al. 2005)]; 9 - the Pontides Unit [north Turkey (Sachanski et al. 2008, 2012)]; 10 - North China [China (Xu 1984)]; 11 - South China [China (Xu 1984), Vietnam (Thanh et al. 2013)]; 12 - East Gondwana [Central Victoria, East Australia (Rickards \& Sandford 1998)]; 13 - Laurentia [Arctic Canada Cornwallis Island (Lenz \& Kozłowska-Dawidziuk 2001, Lenz et al. 2012)].

et al. 2007) and was probably part of Armorican terrane assemblage. According to Sachanski et al. (2008, 2012), P. d. pseudodubius is known from north Turkey in part of the Pontides Unit (Torsvik \& Cooks 2016), which was located near central Gondwana during middle Silurian (Torsvik \& Cocks 2011). There is also a record of P. d. pseudodubius from Libya (Štorch \& Massa 2003) which was part of central Gondwana (Fig. 5).

Pristiograptus $d$. pseudodubius is also recorded from the South and North China palaeocontinents (Xu 1984). Thanh et al. (2013) recorded P. d. pseudodubius from the Quang Ninh Zone of the Bac Bo Region in northeastern Vietnam, part of the South China Plate (Torsvik \& Cooks 2013).

Pristiograptus $d$. pseudodubius has been described from central Victoria in East Australia (Rickards \& Sandford 1998). East Australia makes up part of east Gondwana and was located near the equator during the middle Silurian (Torsvik \& Cocks 2009).

There are very well documented graptolites including P. dubius (Lenz \& Kozłowska-Dawidziuk 2001) and P. dubius s.l. (Lenz et al. 2012) from Wenlock of Arctic Canada, the part of Laurentia. Authors noted considerable variations in the collected specimens, albeit all the material is assigned to a single P. dubius species (Lenz \& Kozłowska-Dawidziuk 2001). Accordingly, it can be assumed that $P$. $d$. pseudodubius might be present in the Arctic Canada.

Pristiograptus lodenicensis, however, is known from very few locations and only from the middle part of the lundgreni Biozone. It is known from Baltica (Latvia, Lithuania and Poland) (Fig. 5). Holland et al. (1969) figured Pristiograptus sp. 1 with cortical tissue (text-fig. 1d) typical of $P$. lodenicensis and illustrated some specimens (pl. 130, figs 5, 6) with the horizontal thecal aperture lips that are typical for $P$. lodenicensis (Fig. 4A). Based on those illustrations, we recognize the existence of P. lodenicensis from the Ludlow district, Shropshire and Denbighshire north-east Wales (Warren et al. 1984), expanding the species' range to the Avalonia palaeocontinent.

There are also $P$. lodenicensis records from Thuringia (Jaeger 1959, 1991) and the Bardo Mountains of the Sudetes (this paper). Both locations are linked to the SaxoThuringian terrane which was located on the opposite side of the Rheic Palaeo-ocean during the Wenlock along with 
the Perunica terrane from which $P$. lodenicensis is also known (Bouček 1932, Přibyl 1943).

Graptolites of the lundgreni Biozone have been studied in Arctic Canada the part of Laurentia (Lenz \& Kozłowska-Dawidziuk 2001, Lenz et al. 2012) but $P$. lodenicensis was not documented. Present all data indicates that $P$. lodenicensis is characteristic for the the Rheic Palaeo-ocean.

\section{Conclusion}

In summary, the long-ranging Pristiograptus $d$. pseudodubius is known from the riccartonensis to parvus biozones and is widespread, from Laurussia to Central Gondwana and East Gondwana. Pristiograptus lodenicensisis is known only from middle part of the lundgreni Biozone and is linked to the palaeogeographical province of the Rheic Palaeo-ocean. This difference in geographical range may be related to $P$. lodenicensis' proposed position as a short-ranged iterative branch off of the $P$. dubius stem lineage (Urbanek et al. 2012), with little opportunity to spread widely after speciation.

\section{Acknowledgements}

We thank David Loydell and Michael Howe for their comments and constructive reviews of manuscript and Petr Štorch for his editorial input. Fieldwork was supported by J. Mianowski Fund (AM-PL-2008-LT- 0142). This study was supported by the grant from the Research Council of Lithuania (S-MIP-19-15) and is a contribution to "IGCP 652: Reading geological time in Paleozoic sedimentary rocks: the need for an integrated stratigraphy".

\section{References}

Belka, Z., Valverde-Vaquero, P., Dörr, W., Ahrendt, H., Wemmer, K., Franke, W. \& Schäfer, J. 2002. Accretion of first Gondwana-derived terranes at the margin of Baltica, 19-36. In Winchester, J.A., Pharaoh, T.C. \& Verniers, J. (eds) Palaeozoic amalgamation of Central Europe. Geological Society of London, Special Publication 201. DOI 10.1144/GSL.SP.2002.201.01.02

Bjerreskov, M. \& Jørgensen, K.Å. 1983. Late Wenlock graptolite bearing tuffaceous sandstone from Bornholm. Bulletin of the Geological Society of Denmark 31, 129-149.

BoučEK, B. 1932. Předběžná zpráva o některých nových druzích graptolitů z českého gotlandienu. Věstník Státního geologického ústavu Československé republiky 7, 150-155.

Chew, D.M. \& Stillman, C.J. 2009. Late Caledonian Orogeny and magmatism, 143-173. In Holland, C.H. \& SANDERS, I.S. (eds) The Geology of Ireland, $2^{\text {nd }}$ ed. Dunedin Academic Press, Edinburgh.
Chorowska, M. \& Oberc, J. 1980. The stratigraphy and tectonics of the uppermost Silurian and Lower Devonian of the Zdanów section (Bardo Mts, Sudetes) in the light of conodont studies. Geological Quarterly 24(2), 193-216.

Cocks, L.R.M., McKerrow, W.S. \& Verniers, J. 2003. The Silurian of Avalonia, 35-53. In Landing, E. \& Johnson, M.E. (eds) Silurian Lands and Seas, Paleogeography outside of Laurentia (Proceedings of the James Hall Symposium, Rochester, NY, USA, August 1996). New York State Museum Bulletin 493.

Colţol, O., Nicolas, G. \& Safa, P. 2016. The assessment of the hydrocarbon potential and maturity of Silurian intervals from eastern part of Moesian Platform - Romanian sector. Marine and Petroleum Geology 77, 653-667.

DOI 10.1016/j.marpetgeo.2016.06.024

DAhlgRÜn, F. \& FincKh, L. 1924. Ein Silurprofil aus dem Warthauer Sehiefergebirge. Jahrbuch der Preußischen Geologischen Landesanstalt zu Berlin 44, 281-289.

DAthe, E. 1904. Erläuterungen zur Geologische Karte von Preußen und benachbarten Bundesstaaten 1:25 000. Blatt Neurode, Lief 115. Berlin.

Doran, R. 1974. The Silurian rocks of the southern part of the Slieve Phelim inlier, Co. Tipperary. Proceedings of the Royal Irish Academy. Section B: Biological, Geological, and Chemical Science 74, 193-202.

Franke, W. 2000. The mid-European segment of the Variscides: tectonostratigraphic units, terrane boundaries and plate tectonic evolution, 35-61. In FranKe, W., HAAK, V., ONCKEN, O. \& Tanner, D. (eds) Orogenic Processes: Quantification and Modelling in the Variscan Belt. Geological Society London, Special Publication 179.

DOI 10.1144/GSL.SP.2000.179.01.05

FRECH, F. 1897. Lethaea geognostica oder Beschreibung und Abbildung für die Gebirgs-Formationen bezeichnendsten Versteinerungen. 1. Teil-Lethaea Palaeozoica. Schweizerbart'sche Verlagshandlung, Stuttgart.

Gailite, L. Rubnikova, M. \& Ulst, R. 1967. Stratigrafia, fauna, i uslovia obrazovania silurijskich porod srednej Pribaltiki. 304pp. Izdatelstvo Zinatne, Riga.

Gürich, G. 1908. Die Leitfossilien. Ein Hilfsbuch zum Bestimmen von Versteinerungen bei geologischen Arbeiten in der Sammlung und im Felde. Erste Lieferung: Kambrium und Silur. 96 pp. Verlag von Gebrüder Borntraeger, Berlin. DOI 10.5962/bhl.title.29890

Holland, C.H., Rickards, R.B. \& Warren, P.T. 1969. The Wenlock graptolites of the Ludlow district, Shropshire, and their stratigraphical significance. Palaeontology 12(4), 663-668.

Howe, M.P.A. 1983. Measurements of thecal spacing in graptolites. Geological Magazine 120(6), 635-638. DOI 10.1017/S0016756800027795

Hund, R. 1924. Die Graptolithen des deutschen Silurs. 96 pp. Verlag Max Weg, Leipzig.

Iordan, M. 1992. Biostratigraphic age indicators in the Lower Palaeozoic successions of the Moesian Platform of Romania. Geologica Carpatica 43(4), 231-233. 
JAEGER, H. 1959. Graptolithen und Stratigraphie des jüngsten Thüringer Silurs. Abhandlungen der deutschen Akademie der Wissenschaften zu Berlin, Klasse für Chemie, Geologie und Biologie 1952(2), 1-197.

JAEGER, H. 1991. Neue Standard-Graptolithenzonenfolge nach der "Großen Krise" an der Wenlock/Ludlow-Grenze (Silur). Neues Jahrbuch für Geologie und Paläontologie, Abhandlungen 182(3), 303-354.

DOI 10.1127/njgpa/182/1991/303

JAEKEL, O. 1889. Über das Alter des sog. Graptolithengesteins mit besonderer Berücksichtigung der in demselben enthaltenen Graptolithen. Zeitschrift der Deutschen Geologischen Gesellschaft 41, 653-716.

JAWOROWSKI, K. 1965. Strop warstw posłęckich w obniženiu litewskim a granica wenlok-ludlow. Geological Quarterly 9(3), 511-526.

Krstić, B., Maslarević, L. \& Sudar, M. 2005. On the Graptolite Schists Formation (Silurian-Lower Devonian) in the Carpatho-Balkanides of eastern Serbia. Annales géologiques de la Peninsule balkanique 66(1-8), 1-8.

DOI 10.2298/GABP0566001K

KRUG von NidDA, O.L. 1853. Graptolithen bei Herzogswalde. Zeitschrift der Deutschen geologischen Gesellschaft 44, 671-672.

KuraŁowicz, E. 1976. Lower Devonian Graptolite Fauna from the Bardo Mts (Sudetes). Acta Geologica Polonica 26(4), 485-488.

LApworth, C. 1873. Notes on the British graptolites and their allies. 1. On an improved classification of the Rhabdophora, part 1. Geological Magazine 10, 500-504. DOI $10.1017 / \mathrm{S} 0016756800469256$

Lenz, A.C. \& KozŁowska-Dawidziuk, A. 2001. Upper Wenlock (Silurian) graptolites of Arctic Canada: preextinction, lundgreni Biozone fauna. Palaeontographica Canadiana 20, $1-61$.

Lenz, A.C., Senior, S.H., KozŁowska, A. \& Melchin, M.J. 2012. Graptolites from the mid Wenlock (Silurian), middle and upper Sheinwoodian, Arctic Canada. Palaeontographica Canadiana 32, 1-93.

Loydell, D.K. \& Walasek, N. 2020. Two new species of graptolites from the Telychian (upper Llandovery, Silurian) of Kallholn, Dalarna, Sweden. GFF, 1-4. DOI 10.1080/11035897.2019.1686419

Loydell, D.K., Frýda, J. \& Gutiérrez-Marco, J.C. 2015. The Aeronian/Telychian (Llandovery, Silurian) boundary, with particular reference to sections around the El Pintado reservoir, Seville Province, Spain. Bulletin of Geosciences 90(4), 743-794. DOI 10.3140/bull.geosci.1564

MalinowsKa, L. 1955. Stratygrafia gotlandu Gór Bardzkich. Biuletynie Instytutu Geologicznego 95, 5-81.

Mazur, S., Aleksandrowski, P., Kryza, R. \& Oberc-Dziedzic, T. 2006. The Variscan Orogen in Poland. Geological Quarterly 50(1), 89-118.

MüNCH, A. 1952. Die Graptolithen aus dem anstehenden Gotlandium Deutschlands und der Tschechoslowakei. Geologica, Schriftenreihe der Geologischen Institute der Universtäten Berlin, Greifswald, Halle, Rostock 7, 1-157.
Oberc, J., Badura, J., Przybylski, B. \& Jamrozik, L. 1994. Bardo Śląskie. Szczegółowa mapa geologiczna Sudetów $1: 25$ 000. Państwowy Instytut Geologiczny Warszawa.

Obut, A., Sobolevskaya, R. \& Bondarev, V. 1965. Graptolity silura Tajmyra. 120 pp. Akademia Nauk SSSR Sibirskoe otdelenie, Institut Geologii i Geofiziki, Moskva.

PAŠKEVIČIUS, J. 1983. Association of the Silurian graptolites in various facies of the South-East Baltic Region. Geologija (Vilnius) 4, 23-40.

Pearson, P. 1998. Speciation and extinction asymmetries in paleontological phylogenies: evidence for evolutionary progress? Paleobiology 24(3), 305-335.

PoręBSKA, E. 1980a. Granica sylur-dewon w profilu Zdanowa wyznaczona na podstawie graptolitow, 35-41. In Gunia, T. (ed.) Rozwój struktury bardzkiej w świetle nowych badań stratygraficznych, sedymentologicznych i tektonicznych. Materiaty Konferencji Terenowej. Srebrna Góra 20-21 września 1980. Wyd. Uniwersytetu Wrocławskiego.

PoręBSKA, E. 1980b. Stratigrafia, litologia i sedymentacja ordovicu? Syluru i dewonu dolnego Gór Bardzkich, 23-34. In Gunia, T. (ed.) Rozwój struktury bardzkiej w świetle nowych badań stratygraficznych, sedymentologicznych i tektonicznych. Materiaty Konferencji Terenowej, Srebrna Góra 20-21 września 1980. Wyd. Uniwersytetu Wrocławskiego.

PoręBSKA, E. 1982. Latest Silurian and Early Devonian graptolites from Żdanów section, Bardo Mts. (Sudetes). Annales Societatis Geologorum Poloniae 52, 89-209.

Porębska, E. \& Koszowska, E. 2001. Mazuelloidy - apatytowe glony z dolnego paleozoiku Gór Bardzkich (Sudety). Przegląd Geologiczny 49(11), 1050-1060.

Porębska, E. \& SawŁowicz, Z. 1997. Palaeoceanographic linkage of geochemical and graptolite events across the Silurian-Devonian boundary in Bardzkie Mountains (Southwest Poland). Palaeogeography, Palaeoclimatology, Palaeoecology 132, 343-354.

DOI 10.1016/S0031-0182(97)00048-5

Přıbyl, A. 1943. Revise zástupců rodu Pristiograptus, ze skupiny $P$. dubius a $P$. vulgaris z českého a cizího siluru. Věstnik Královské České Společnosti Nauk, Praha, třída mathematicko-prírodovědecká, Ročník 53 (4), 1-48.

Quieroz, K. DE 1998. The general lineage concept of species, species criteria, and the process of speciation: a conceptual unification and terminological recommendations, 57-75. In Berlocher, S. \& Howard, D. (eds) Endless forms: species and speciation. Oxford University Press.

Quieroz, K. DE 2007. Species concepts and species delimitation. Systematic Biology 56(6), 879-886. DOI 10.1080/10635150701701083

Radzevičius, S. 2003. Pristiograptus (Graptoloidea) from the perneri - lundgreni biozones (Silurian) of Lithuania. Carnets de Geologie. Article 2003/01, 1-15. DOI 10.4267/2042/300

RAdZEvičIus, S. 2006. Late Wenlock biostratigraphy and the Pristiograptus virbalensis group (Graptolithina) in Lithuania and the Holy Cross Mountains. Geological Quarterly 50(3), 333-344.

RadzeviČIUs, S. \& PAšKeVIČıus, J. 2000. Pristiograptids (Grapto- 
loidea) and their adaptive types of the Wenlock (Silurian) in Lithuania. Geologija (Vilnius) 32, 88-109.

Radzevičius, S. \& PAšKevičius, J. 2005. Pristiograptus (Graptoloidea) from the Upper Wenlock of the Baltic countries. Stratigraphy and Geological Correlation 13(2), 159-169.

Radzevičıus, S., PašKevičıus, J. \& Meidla, T. 2008. Kai kurių silūro graptolitų evoliucija ir filogenija. Geologijos akiračiai 2, 35-42.

Rickards, R. 1965. New Silurian graptolites from the Howgill Fells (northern England). Palaeontology 8(2), 247-271.

RickARDS, R. \& SANDFORD, A. 1998. Llandovery-Ludlow graptolites from central Victoria: new correlation perspectives of the major formations. Australian Journal of Earth Sciences 45(5), 743-763. DOI 10.1080/08120099808728430

Rickards, R.B. \& Wright, A.J. 2003. The Pristiograptus dubius (Suess, 1851) species group and iterative evolution in the Mid- and Late Silurian. Scottish Journal of Geology 39, 61-69. DOI 10.1144/sjg39010061

Rickards, R., Burns, V. \& Archer, J. 1973. The Silurian sequence at Balbriggan, Co. Dublin. Proceedings of the Royal Irish Academy. Section B: Biological, Geological, and Chemical Science 73, 303-316.

Ruban, D.A., Al-Husseini, M.I. \& Iwasaki, Y. 2007. Review of Middle east Paleozoic plate tectonics. GeoArabia 12(3), 35-56.

Sachanski, V., GöncüoĞLu, M.C. \& Gedik, I. 2008. Wenlock (Silurian) graptolitic shales from the Kocaeli Peninsula (Derince-Izmit), NW Turkey. Acta Geologica Polonica 58(4), 387-393.

SAchanski, V., GöncüoĞlu, M.C., Lakova, I., Boncheva, I. \& Demiray, S.G. 2012. Silurian graptolite, conodont and cryptospore biostratigraphy of the Gülüç, section in Ereğli, Zonguldak Terrane, NW Anatolia, Turkey. Turkish Journal of Earth Sciences 21(6), 867-903.

Servais, T. \& Sintubin, M. 2009. Avalonia, Armorica, Perunica: terranes, microcontinents, microplates or palaeobiogeographical provinces? Geological Society London, Special Publication 325(1), 103-115. DOI 10.1144/SP325.5

ŠTorch, P. \& MASSA, D. 2003. Biostratigraphy, correlation, environmental and biogeographic interpretation of the lower Silurian graptolite faunas of Libya, 237-251. In SALEM, M. \& Oun, K. (eds) The Geology of Northwest Libya 1.

ŠTorch, P. \& MASSA, D. 2006. Middle Llandovery (Aeronian) graptolites of the western Murzuq Basin and Al Qarqaf Arch region, South-West Libya. Palaeontology 49(1), 83-112. DOI 10.1111/j.1475-4983.2005.00530.x

ŠTorch, P. \& PIRAS, S. 2009. Silurian graptolites of Sardinia: assemblages and biostratigraphy. Rendiconti della Società Paleontologica Italiana 3(1), 77-93.

Teller, L. 1959. Problem warstw zdanowskich oraz granica sylur-dewon w Gór Bardzkich. Przegląd Geologiczny 7(1), 21-23.

Teller, L. 1960. Poziom Monograptus hercynicus z warstw zdanowskich w Górach Bardzkich. Acta Geologica Polonica 10(3), 325-335.
Thanh, T., Phuong, T., Janvier, P., Hùng, N., Cúc, N. \& Duong, N. 2013. Silurian and Devonian in Vietnam - stratigraphy and facies. Journal of Geodynamics 69, 165-185.

DOI 10.1016/j.jog.2011.10.001

Torsvik, T.H. \& Cocks, L.R.M. 2004. Earth geography from 400 to 250 Ma: a palaeomagnetic, faunal and facies review. Journal of the Geological Society 161(4), 555-572. DOI 10.1144/0016-764903-098

Torsvik, T.H. \& Cocks, L.R.M. 2009. The Lower Palaeozoic palaeogeographical evolution of the northeastern and eastern peri-Gondwanan margin from Turkey to New Zealand. Geological Society London, Special Publication 325(1), 3-21. DOI 10.1144/SP325.2

Torsvik, T.H. \& Cocks, L.R.M. 2011. The Palaeozoic palaeogeography of central Gondwana. Geological Society London, Special Publication 357(1), 137-166.

DOI 10.1144/SP357.8

Torsvik, T.H. \& Cocks, L.R.M. 2013. New global palaeogeographical reconstructions for the Early Palaeozoic and their generation. Geological Society London, Memoir 38(1), 5-24. DOI 10.1144/M38.2

TorsviK, T.H. \& Cocks, L.R.M. 2016. Earth history and palaeogeography. 317 pp. Cambridge University Press. DOI 10.1017/9781316225523

ULST, R. 1974. The early sequence of pristiograptids in conterminous deposits of Wenlock and Ludlow of the middle Pribaltic, 105-122. In Овит, A. (ed.) Graptolites of the USSR. Novosibirsk, Russia.

Ulst, R. 1988. O graptolitovoy zonal'nostu silura Pribaltiki, 70-74. In PAšKevičius, J., Jurgaitis, A. \& MiKšYs, M. (eds). Graptolites in the Earth History, Abstracts $5^{\text {th }}$ Symposium on investigation of Graptolites in USSR.

Urbanek, A. 1958. Monograptidae from erratic boulders of Poland. Palaeontologica Polonica 9, 1-105.

URBANEK, A. 2003. Organization and evolution of animal colonies. Biology Bulletin 30(1), 1-8. DOI 10.1023/A:1022045523949

Urbanek, A. \& Uchmanski, J. 1990. Morphogenesis of uniaxiate graptoloid colonies - a mathematical model. Paleobiology 16(1), 49-61. DOI 10.1017/S0094837300009726

Urbanek, A., Radzevičius, S., KozŁowska, A. \& Teller, L. 2012. Phyletic evolution and iterative speciation in the persistent Pristiograptus dubius lineage. Acta Palaeontologica Polonica 57(3), 589-611. DOI 10.4202/app.2010.0070

Warren, P.T., Price, D., Nutt, M.J.C. \& Smith, E.G. 1984. Geology of the country around Rhyland Denbigh. Memoir for 1 : 50000 geological sheets 95 and 107 and parts of sheets 94 and 106. 217 pp. British Geological Survey.

Whittingham, M., Radzevičius, S. \& Spiridonov, A. 2020. Moving towards a better understanding of iterative evolution: an example from the Late Silurian Monograptidae (Graptolithina) of the Baltic Basin. Palaeontology 63, 1-21.

DOI 10.1111/pala.12477

Winchester, J., Pharaoh, T. \& Verniers, J. 2002. Palaeozoic amalgamation of Central Europe: an introduction and synthesis of new results from recent geological and geophysical investigations, 1-18. In Winchester, J.A., Pharaoh, T.C. \& Verniers, J. (eds) Palaeozoic Amalgamation of Central 
Europe. Geological Society London, Special Publication 201. DOI 10.1144/GSL.SP.2002.201.01.01

WyżGA, B. 1987. Lower Palaeozoic of Bardo Mountains (Sudetes): a sequence of deep sea pelagic sediments. Geologia Sudetica 22, 119-145.

Xu, C. 1984. The Silurian graptolite zonation of China. Canadian Journal of Earth Science 21, 241-257. DOI 10.1139/e84-025
Zalasiewicz, J. \& Williams, M. 1999. Graptolite biozonation of the Wenlock Series (Silurian) of the Builth Wells district, central Wales. Geological Magazine 136(3), 263-283. DOI 10.1017/S0016756899002599

Żelaźniewicz, A. \& Aleksandrowski, P. 2008. Regionalizacja tektoniczna Polski - Polska południowo-zachodnia. Przegląd Geologiczny 56(10), 904-911. 